\title{
THE DISAPPEARING CRYOSPHERE IN THE SOUTHEASTERN ALPS: INTRODUCTION TO SPECIAL ISSUE
}

Matija Zorn, Blaž Komac, Anne Carey, Mauro Hrvatin, Rok Ciglič, Berry Lyons

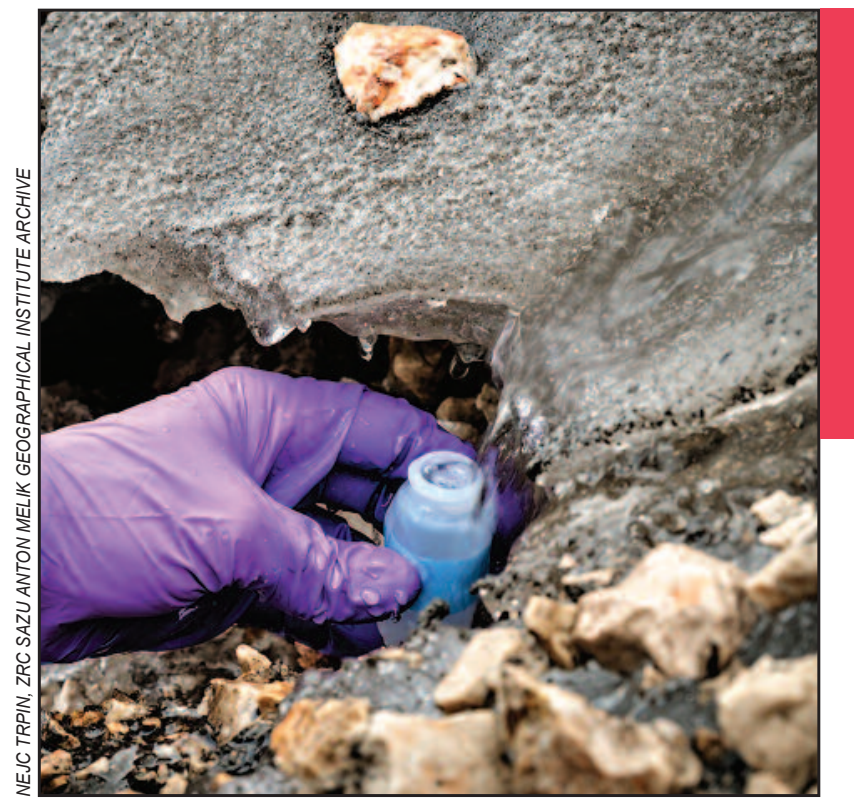

The cryosphere in the southeastern Alps is melting away. Sampling meltwater from the Triglav Glacier in 2017. 
DOI: https://doi.org/10.3986/AGS.9396

UDC: $911.2: 551.32(234.3)$

COBISS: 1.02

\section{Matija Zorn ${ }^{1}$, Blaž Komac ${ }^{1}$, Anne Carey ${ }^{2}$, Mauro Hrvatin ${ }^{1}$, Rok Ciglič ${ }^{1}$, Berry Lyons ${ }^{2}$}

\section{The disappearing cryosphere in the southeastern Alps: Introduction to special issue}

ABSTRACT: Various ice bodies are an important source of paleoenvironmental data, and their study improves the understanding of present and future environmental conditions. Their changes are an important indicator of climate change. This special issue of Acta geographica Slovenica draws attention to the changing and disappearing cryosphere across the globe, with an emphasis on the southeastern Alps, and the necessity to conduct research in this field before the ice disappears forever. This paper briefly summarizes the current body of knowledge on glaciers, permafrost, cave ice, lake and river ice, and snow in the southeastern Alps, and it presents the contribution of Acta geographica Slovenica to this research and the main highlights of all five papers included in this special issue.

KEY WORDS: cryosphere, glaciers, permafrost, cave ice, ice, climate change, Alps, Slovenia

\section{Izginjajoča kriosfera v jugovzhodnih Alpah: uvodnik k posebni izdaji}

POVZETEK: Različna ledena telesa so pomemben arhiv paleookoljskih podatkov in njihovo preučevanje pripomore $\mathrm{k}$ boljšemu razumevanju sedanjih in prihodnjih okoljskih razmer. Njihovo spreminjanje je pomemben kazalnik podnebnih sprememb. S to posebno izdajo revije Acta geographica Slovenica želimo opozoriti na spreminjanje in izginjanje kriosfere po svetu, še posebej pa na območju jugovzhodnih Alp, ter na nujnost raziskav na tem področju, preden led za vedno izgine. V članku je na kratko predstavljeno znanje o ledenikih, permafrostu, ledu v jamah, ledu na jezerih in rekah ter snegu v jugovzhodnih Alpah, poudarjen pa je tudi prispevek revije Acta geographica Slovenica k tem raziskavam, kot tudi glavni poudarki vseh petih člankov, ki tvorijo to posebno izdajo.

KLJUČNE BESEDE: kriosfera, ledeniki, permafrost, led v jamah, led, podnebne spremembe, Alpe, Slovenija

The paper was submitted for publication on December $14^{\text {th }}, 2020$.

Uredništvo je prejelo prispevek 14. decembra 2020.

\footnotetext{
${ }^{1}$ Research Centre of the Slovenian Academy of Sciences and Arts, Anton Melik Geographical Institute, Ljubljana, Slovenia matija.zorn@zrc-sazu.si (https://orcid.org/0000-0002-5788-018X), blaz.komac@zrc-sazu.si (https://orcid.org/0000-0003-4205-5790), mauro.hrvatin@zrc-sazu.si (https://orcid.org/0000-0002-6021-8736), rok.ciglic@zrc-sazu.si (https://orcid.org/0000-0003-3517-3780)

2 The Ohio State University, School of Earth Sciences, Byrd Polar and Climate Research Center, Columbus, Ohio, USA carey.145@osu.edu (https://orcid.org/0000-0002-0272-5254), lyons.142@osu.edu (https://orcid.org/0000-0002-3143-7251)
} 


\section{Introduction}

Various ice bodies are an important source of paleoenvironmental data (e.g., Brook and Buizert 2018; Lipar, Zorn and Perko 2021). Their changes reflect climate change, and their study improves the understanding of present and future environmental conditions. The existence of ice bodies is under threat and, along with this, an important source of environmental data. Glaciers in the European Alps alone lost around 50\% of their volume between the end of the Little Ice Age (from approximately 1850) and 1975, about 10\% from 1975 to 2000, and an additional 10\% from 2000 to 2009 (Kaufmann et al. 2015; Figure 1). Predictions that glaciers in the Alps will shrink to half their current size by 2050 (Zekollari, Huss and Farinotti 2019) and almost completely disappear by 2100 are alarming from the viewpoint of preserving the cryosphere and hence an important "archive « of data on the paleoenvironment. A very revealing piece of information for how fast the global ice is disappearing is that from 1994 to 2017 the volume of ice on the Earth's surface decreased by 28 trillion tons, and that the loss of over two-thirds of ice is connected with atmospheric melting (Slater et al. 2020).

This special issue of Acta geographica Slovenica draws attention to the changing and disappearing cryosphere in the southeastern Alps and elsewhere across the globe, and the necessity to conduct research in the areas that are under threat of soon being left without permanent ice and thus an important source of data on the past environment. In addition, the publication of the sixtieth volume of the journal (Zorn and Komac 2010; Ciglič et al. 2020) this year provides a good opportunity to highlight its importance in presenting material on the cryosphere in the southeastern Alps (Section 9).

To date, a total of forty-one papers related to the cryosphere have been published in Acta geographica Slovenica, which is a twelfth of all papers. Most were connected with both Slovenian glaciers (more than two-fifths of all papers on the cryosphere; see Section 9.1 for references), followed by papers examining past glaciations (just over a fourth; see Section 9.2 for references), snow and avalanches, and ice and geochemistry (just under a third; see Section 9.3 for references).

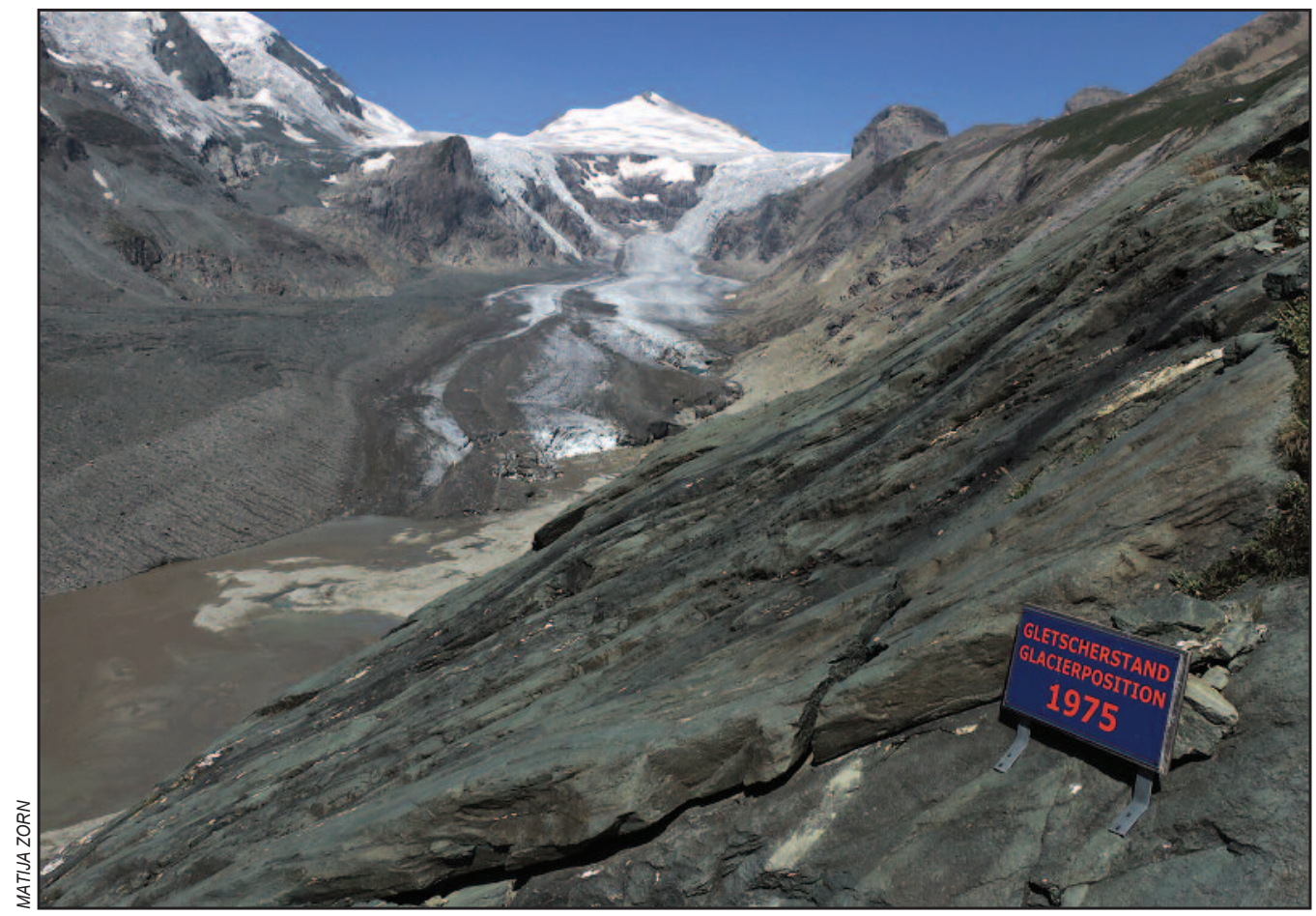

Figure 1: The Pasterze Glacier (Austria), the largest glacier in the eastern Alps, has shrunk by approximately a third since the end of the Little Ice Age (Kaufmann et al. 2015). The sign shows the edge of the glacier in 1975, and the photo shows its size in 2015. 


\section{Glaciers}

Acta geographica Slovenica has been covering the developments on glaciers in the southeastern Alps for several decades. The first papers on this topic were already published in 1955, in the journal's third volume (Section 9.1), which means that already in the mid-twentieth century the journal became involved in what is currently a very topical scholarly discussion on the cryosphere. Most papers on this topic are connected with studies of the Triglav Glacier (e.g., Gabrovec et al. 2013) and the Skuta Glacier, which the ZRC SAZU Anton Melik Geographical Institute has been heading ever since 1946. Changes in both glaciers reflect climate change, which is one of the reasons that changes in the Triglav Glacier are included in the environmental indicators that the Slovenian Environment Agency uses to monitor climate change in Slovenia (Triglav ... 2019).

Even up until recently it was assumed that the two glaciers in their present shape formed during the Little Ice Age (Gabrovec et al. 2014), but the latest research indicates that they may have persisted throughout the entire Holocene (Lipar et al. 2021).

Changes in glaciers in the southeastern Alps and elsewhere around the globe are connected with rising temperatures (Figure 2). In the area of the Triglav Glacier in the Julian Alps (southeastern Alps), at an elevation of approximately $2,500 \mathrm{~m}$, the average annual temperature between 1961 and 2018 rose by a full $2.03^{\circ} \mathrm{C}$ (Figure 3; Hrvatin and Zorn 2020).

\section{Permafrost}

Due to their geographical location and elevation, the southeastern Alps, including the Slovenian Alps, only have marginal permafrost areas. Because no research on permafrost in Slovenia has (yet) been conducted, its dimensions can only be inferred indirectly from the temperature and partly from geomorphological conditions. Based on the average annual temperature of $0{ }^{\circ} \mathrm{C}$, which in the southeastern Alps is typical at an elevation between 2,400 and 2,500 $\mathrm{m}$, it can be assumed that permafrost is possible at the highest elevations of the Julian Alps (northwest Slovenia) and the Kamnik-Savinja Alps (northern Slovenia). However, because the high mountains in the southeastern and Slovenian Alps are predominantly composed of carbonate rock and karstified, so that in the summer rainwater can percolate through the rock, it is also less likely that permafrost has remained frozen there since the last ice age (Vrhovec 2004).

According to Boeckli et al. (2012), who designed the Alpine Permafrost Index Map, the country with the most permafrost in the Alps is Switzerland, followed by Italy, Austria (Figure 4), France, and Germany. Slovenia and Liechtenstein only have negligible areas of permafrost. In the Alpine countries, areas of permafrost are believed to be larger than areas covered in glaciers; they are estimated to cover up to $3 \%$ of the entire Alps, but only from $0.1 \mathrm{~km}^{2}$ to $25.7 \mathrm{~km}^{2}$ in Slovenia.

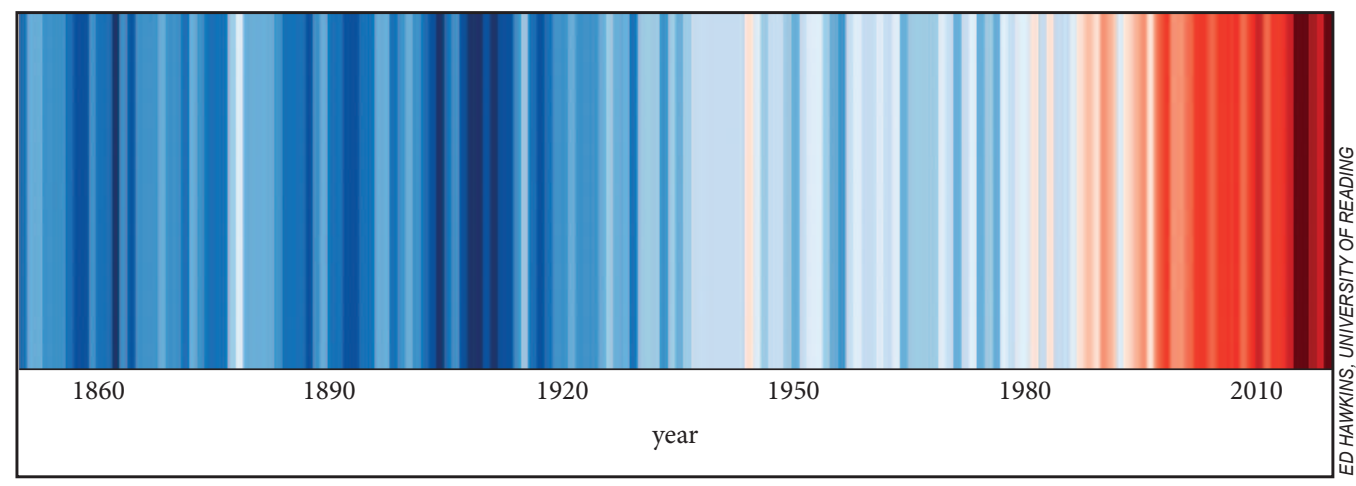

Figure 2: The warming stripes show global temperature change between 1850 and 2019 (Show ... 2020). According to the World Meteorological Organization, 2015-2019 was the warmest five-year period on record, and 2010-2019 was the warmest decade on record. Since the 1980s, each successive decade has been warmer than any preceding decade since 1850 (Hawkins 2020; WMO Statement ... 2020). 


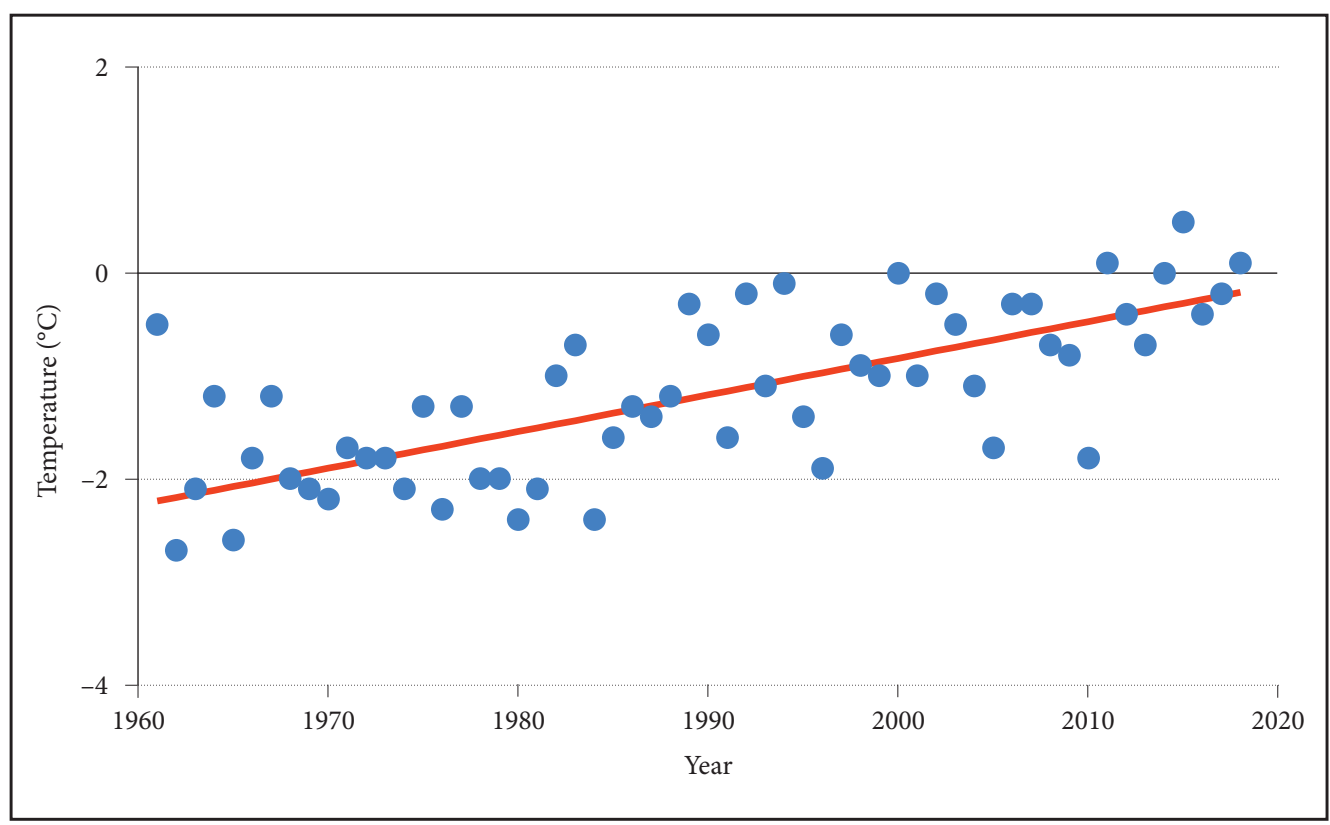

Figure 3: Average annual temperature trend at the Kredarica temperature station in the Julian Alps (southeastern Alps) at 2,513 m, 1961-2018. Between 1961 and 2018, the average annual temperature rose by $2.03^{\circ} \mathrm{C}$ (Hrvatin and Zorn 2020).

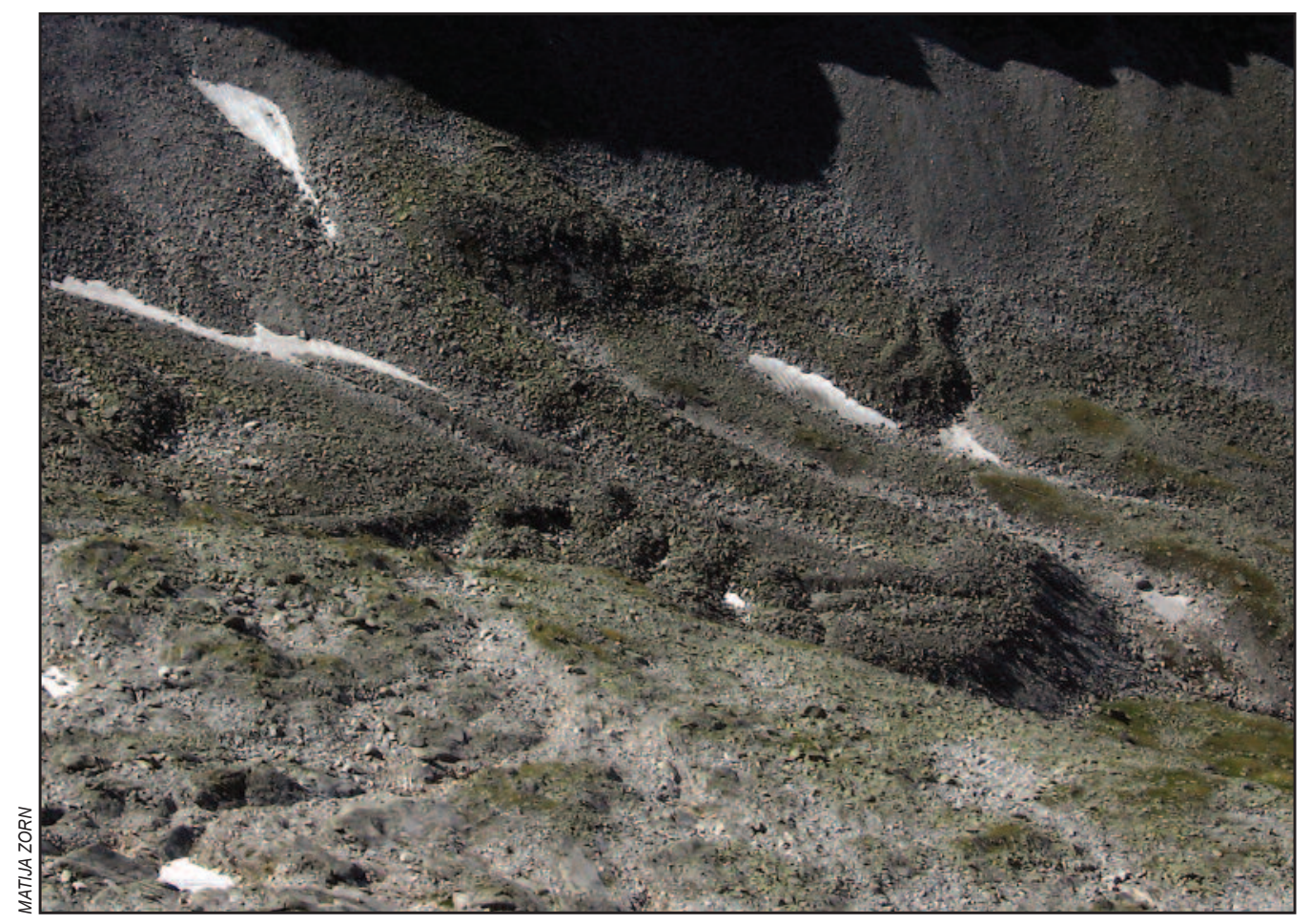

Figure 4: The Dösen Rock Glacier in the High Tauern (Central Austria; Kellerer-Pirklbauer, Lieb and Kaufmann 2017) contains a permanent ice body. 
However, many remnants of permafrost from previous environmental conditions can also be found in the southeastern Alps (Gabrovec et al. 2014; Colucci et al. 2016a; Triglav Čekada et al. 2016). Certain karst caves can feature active patterned ground likely related to seasonal frost heaving (Gams 1971; Obu et al. 2018; Oliva et al. 2018; Mihevc and Urbančič 2019), and on the surface, such as the western side of Mount Triglav, effects of permafrost on sediments can be seen (Šifrer 1963; Gabrovec et al. 2014).

In deep karst depressions, strong temperature inversion is related to the cave climate, which in turn influences surface landforms. Mihevc $(2015,2018)$ found patchy permafrost in these depressions due to subterranean air circulation through karst.

In the Alps, problems with permafrost disappearing due to climate change are primarily manifested in an increasing rockfall trend (Vrhovec 2003, 2004; Noetzli, Hoelzle and Haeberli 2003; Gruber, Hoelzle and Haeberli 2004; Bodin et al. 2015), but a great deal of high-mountain infrastructure (Haeberli et al. 2010; Hock et al. 2019) and hence tourism is also under threat (Urbanc and Pipan 2013; Ritter, Fiebig and Muhar 2012). It is estimated that due to global warming 10\% of the infrastructure in the French Alps is characterized by a high risk of destabilization (Duvillard, Ravanel and Deline 2015).

\section{Cave ice}

Changes in the volume of ice in the southeastern Alps can be observed not only in the glaciers, but also in ice caves (Mihevc 2018; Carey et al. 2019). Permanent ice in caves is also a form of permafrost. In the cave register of Slovenia, permanent ice is reported in over 550 caves (Mihevc 2018), which are not limited only to the high mountains. Most of them have an entrance at an elevation between 1,000 and 2,400 $\mathrm{m}$. With regard to the southeastern Alps, Colucci et al. (2016b) report that the climate thresholds for ice caves include a mean summer air temperature $<13^{\circ} \mathrm{C}$ and a mean winter air temperature $<-2{ }^{\circ} \mathrm{C}$. In the southeastern Alps, some caves also exhibit relict permafrost and cryotic conditions in the rock (Colluci and Guglielmin 2019).

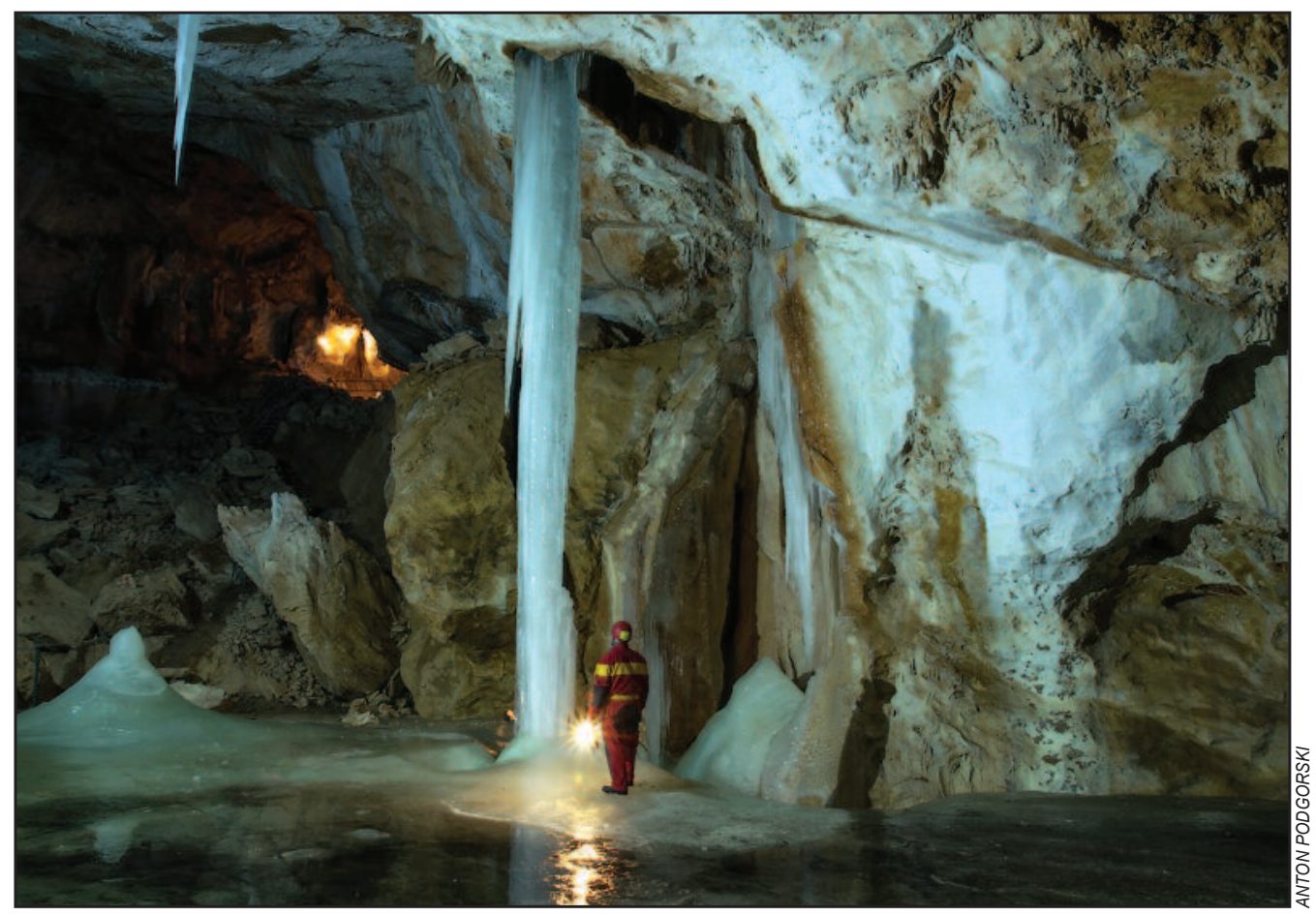

Figure 5: The main ice gallery in Snežna Cave. 
Just like surface glaciers, »cave glaciers« are indicators of climate change. With regard to the Jura Mountains between Switzerland, France, and Germany, Luetscher, Jeannin and Haeberli $(2005,982)$ report that the »equilibrium line altitude of ice caves is believed to have increased several hundred metres « over approximately the past quarter of the twentieth century.

In Slovenia the most studied ice caves are Paradana Cave, Snežna Cave, and the Triglav Shaft. Paradana Cave (western Slovenia; entrance at $1,135 \mathrm{~m}$ ) has an estimated ice volume of about $8,000 \mathrm{~m}^{3}$. There have been documented gains and losses of ice since 1950, with an increased loss since 1986 (Mihevc 2018). Snežna Cave (northern Slovenia; entrance at $1,514 \mathrm{~m}$ ) has about $4,000 \mathrm{~m}^{3}$ of ice. Observations of the cave ice date back to 1980, when the ice and snow at the entrance melted and allowed entrance into the cave. Since then, the volume of snow and ice at the entrance has dropped, and the level of ice in the main ice gallery (Figure 5) dropped more than $1 \mathrm{~m}$ (Mihevc 2018). The discovery of the Triglav Shaft (northwest Slovenia; entrance at 2,377 m) is also connected to climate change because its entrances were covered by the Triglav Glacier until the early twentieth century (Gams 1961; Tičar et al. 2018). Very recently, the geochemistry of ice and stable isotopes from these ice caves were studied by Carey et al. $(2019,2020)$. The results show that the ice in the caves originates from local precipitation modified by the addition of $\mathrm{Ca}^{2+}$ and $\mathrm{HCO}_{3}$ from the dissolution of the local bedrock, and that the isotopic profiles are similar to those of other ice caves in central and eastern Europe.

Ice caves represent the smallest portion of the terrestrial cryosphere because the largest cave ice bodies generally have a volume of up to 150,000 $\mathrm{m}^{3}$ (Kern and Perșoiu 2013). The ice in caves preserves environmental archives because it contains proxies such as chemicals, pollen grains, and macrofossils (Perşoiu and Lauritzen 2018; Perşoiu and Onac 2019). However, the complexity of ice in caves is greater and less understood compared to surface ice (Lipar, Zorn and Perko 2021). Because ice caves occur at lower elevations and lower latitudes than glaciers generally do, they provide a unique paleoenvironmental source in those regions.

\section{Lake and river ice}

In addition to a reduction in permanent ice, global warming and the subsequent warming of standing and running inland waters also reduce the number of days in winter when lakes and rivers are covered in ice. From 1918/19 to 1929/30, ice appeared on Lake Bohinj (the Julian Alps, elevation: $526 \mathrm{~m}$ ) 54.6 days a year on average, from 1961 to 1990 it appeared 50.6 days, and from 1991 to 2001 only 30.9 days (Frantar 2004; Frantar and Uhan 2005). According to the United States Environmental Protection Agency, which uses lake ice as a climate change indicator, the lakes are generally freezing later than they did in the past and show a trend toward earlier ice breakup in the spring (Climate ... 2020). For the northern hemisphere, Magnuson et al. $(2000,1743)$ showed for ice on lakes and rivers (Figure 6) that in the period from 1846

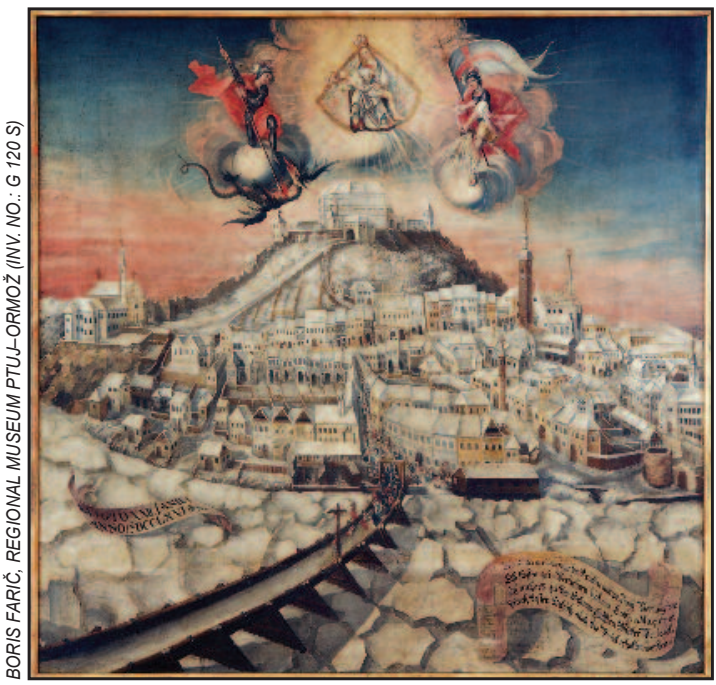

Figure 6: Ice on the Drava at Ptuj (east Slovenia). The 1766 votive painting was commissioned by the residents of Ptuj as an act of gratitude to the town's patron saints for protecting the bridge against the ice jam. This threat is also reported in the sources later on, such as in the second half of the nineteenth century, when the blocks of ice were over a meter thick (Kolar 2019). 
to 1995 »changes in freeze dates averaged 5.8 days per 100 years later, and changes in breakup dates averaged 6.5 days per 100 years earlier.« Somewhat downstream from Slovenia, where the Drava River forms the border between Hungary and Croatia, ice freezes approximately nine days later and breaks up approximately ten days earlier than in 1875 . The duration of ice-cover on the Drava River decreased by fourteen days on a century average, and the number of total ice-affected days decreased by thirty-one days on a century average (Takács and Kern 2015).

\section{Snow and river discharge}

In addition to glaciers (Huss 2011) and cave ice, snow is also an important factor for freshwater storage in high-mountain karst areas of the southeastern Alps. In the spring and early summer, snow feeds many springs, but changes are also observed in the hydrological regime. In the Slovenian Alps, the annual number of days with snow cover from 1961 to 2018 saw a statistically significant decrease by 31 to 56 days, or by $22 \%$ to $67 \%$ at elevations between approximately 500 and $1,000 \mathrm{~m}$ (Figure 7 ). The exception is the highmountain station on Mount Kredarica, where the decrease is less than $3 \%$.

The consequences can be seen in the annual river discharges, in which, however, the afforestation of the mountainous (cultural) landscape (Gabrovec, Bičík and Komac 2019) and the resulting increased evapotranspiration must also be taken into account. The minimum annual discharge trends and the mean annual discharge trends in rivers in the southeastern Alps are decreasing; the latter are mostly between $10 \%$ and $25 \%$ (Figure 8 ). The maximum annual discharge trends are also decreasing for some rivers. Lower snow quantity and higher winter temperatures are changing the discharge regimes (Hrvatin and Zorn 2020).

From 1961 to 1990, Slovenian Alpine rivers were characterized by a distinctive snow-rain discharge regime (Hrvatin 1998). Because of snow retention, the discharge was the lowest in the winter and the main discharge maximum occurred in the spring due to melting snow. A secondary minimum followed in the summer, and after that a secondary maximum due to autumn rain.

From 1991 to 2018, the autumn discharge maximum exceeded the spring maximum for most mountain rivers, and the summer minimum has already become very close to the winter one. Because of the reduced volume and duration of snow cover and increasingly pronounced evapotranspiration, there has been a noticeable decrease in the discharge in late spring and early summer, and a discharge increase between October and December, implying that, because of the rising temperatures and thus less snowfall and more rainfall, winter in the mountains is "running late (Table 1; Hrvatin and Zorn 2017, 2020).

In future climatic and hydrological conditions of the Alps, the glacierized basins might contribute 55 to $85 \%$ less water to streamflow runoff by the end of the twenty-first century (Huss 2011), and substantial reduction is especially expected for the summer (Weber et al. 2010). Water scarcity will affect not only the Alps, but also their densely populated surroundings (Nared, Razpotnik Visković and Komac 2015). The population in the Alps is approximately fourteen million (Price et al. 2011), but also taking into account their immediate surroundings this number increases to approximately seventy million (Which ... 2020). Hydrological changes are already so pronounced (e.g., Gibson 2020) that Alpine countries are formulating common strategies against water scarcity (Water Management ... 2011). In addition, the importance of Alpine rivers' discharge as a source of hydroelectric power must also not be overlooked (Razani et al. 2018).

With regard to snow in the Slovenian Alps, avalanches are by far the most studied phenomena (e.g., Gams 1955; Pavšek 2002; Volk Bahun 2020) and they were already presented in the third volume of Acta geographica Slovenica (see Section 9.3). In Slovenia, a few studies have examined snow cover in relation to water accumulation (Ogrin 2005; Ogrin and Ortar 2007), but research on the isotopic composition of snow is still in its infancy, as is also the case with ice (e.g., Vreča et al. 2013).

\section{Papers in the special issue}

This special issue adds a regional and global note to research on the cryosphere in the southeastern Alps. Thus, in addition to three papers examining the two Slovenian glaciers and ice (Carey et al. 2020; Triglav Čekada and Zorn 2020; Triglav Čekada et al. 2020), there is one paper discussing changes in glaciers in the southeastern Europe (Gachev 2020) and one paper on Antarctica, which provides a global dimension to the special issue (Lyons et al. 2020). 


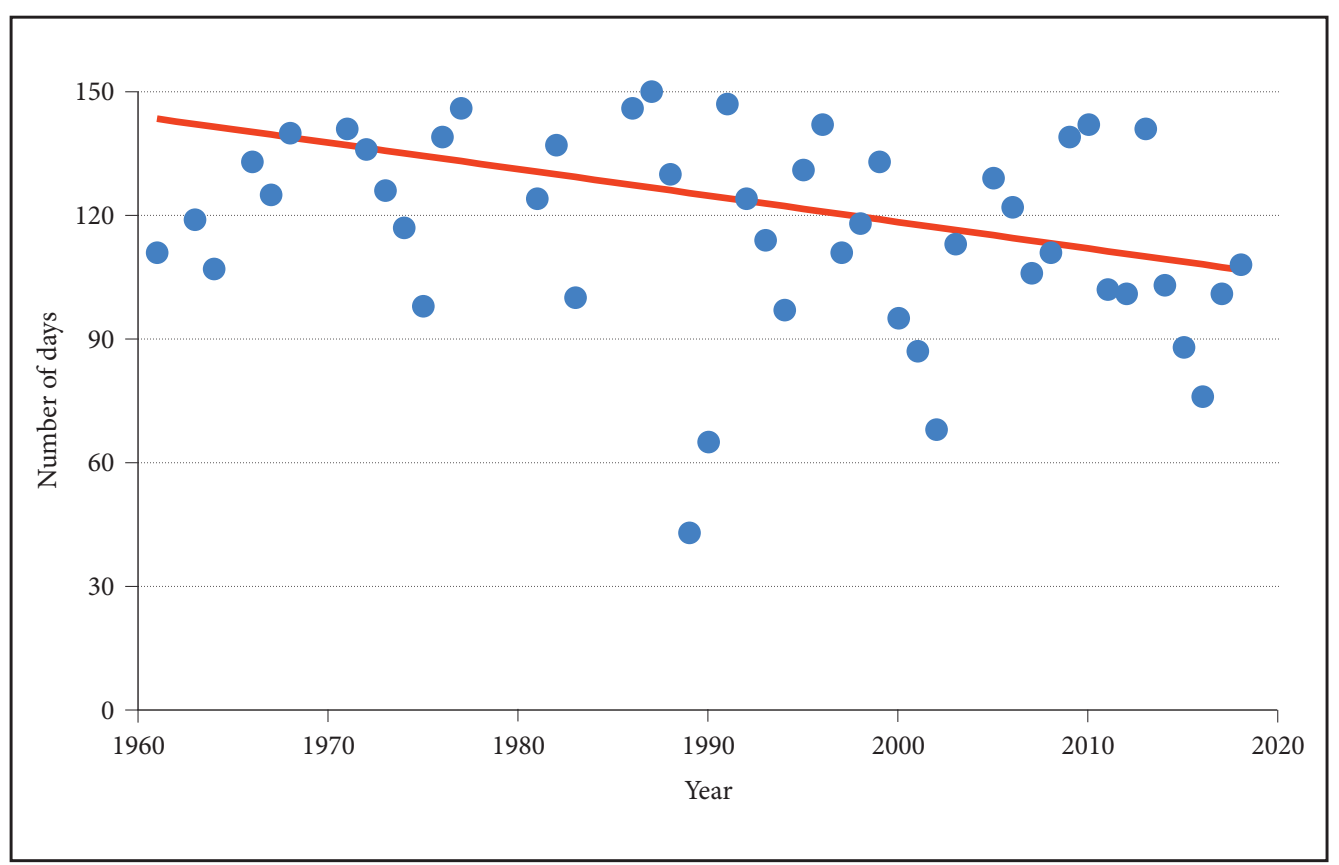

Figure 7: Trends in the annual days with snow cover at the Rateče precipitation station on the northern edge of the Julian Alps (southeastern Alps) at $864 \mathrm{~m}, 1961-2018$. The number of days with snow cover decreased by a full thirty-six days or just over a quarter (Hrvatin and Zorn 2020).

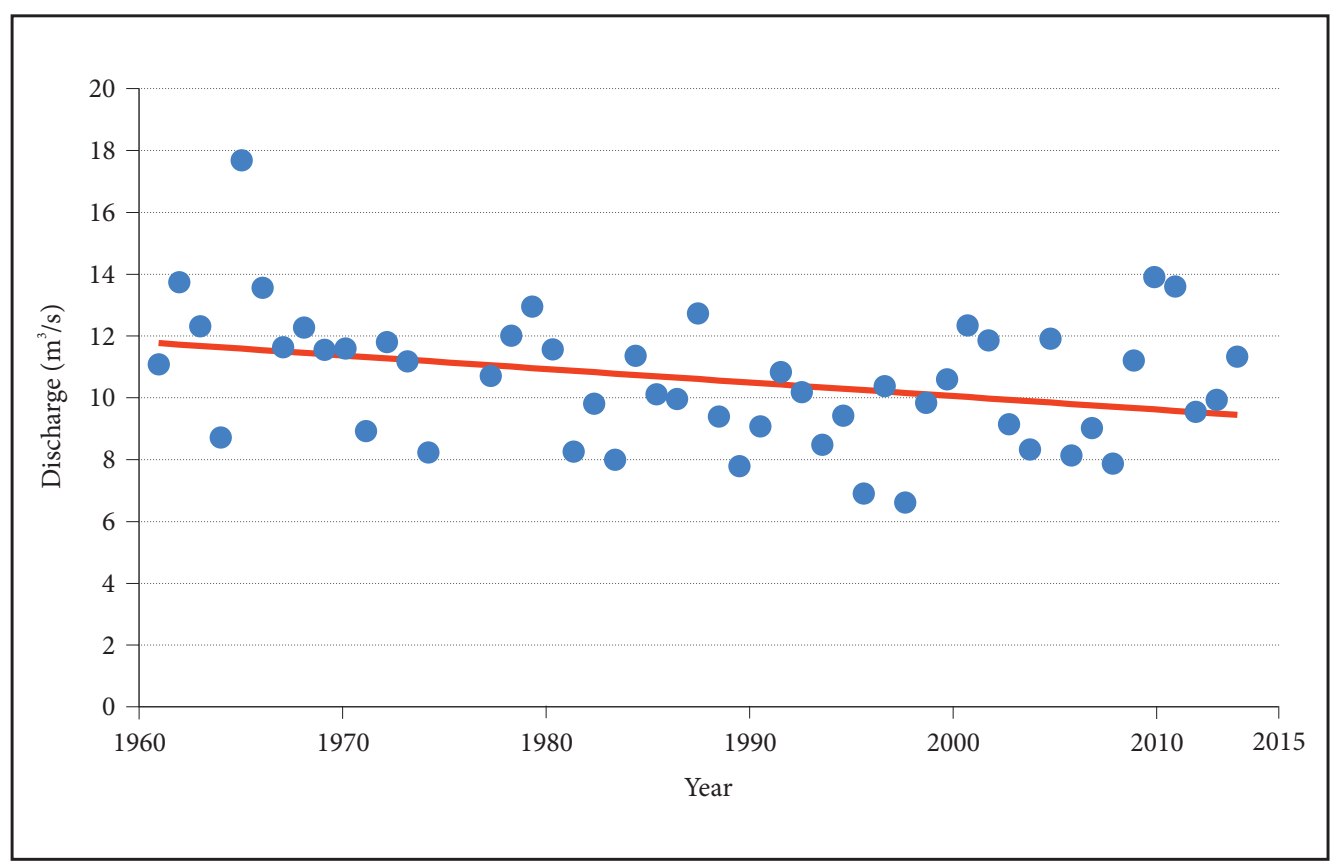

Figure 8: Mean annual discharge trend of the Sava Dolinka River at the Jesenice gauging station on the northeastern edge of the Julian Alps (southeastern Alps) with a drainage area of $257.56 \mathrm{~km}^{2}, 1961-2013$. The mean annual discharge trend decreased by just over a fifth (Hrvatin and Zorn 2020). 


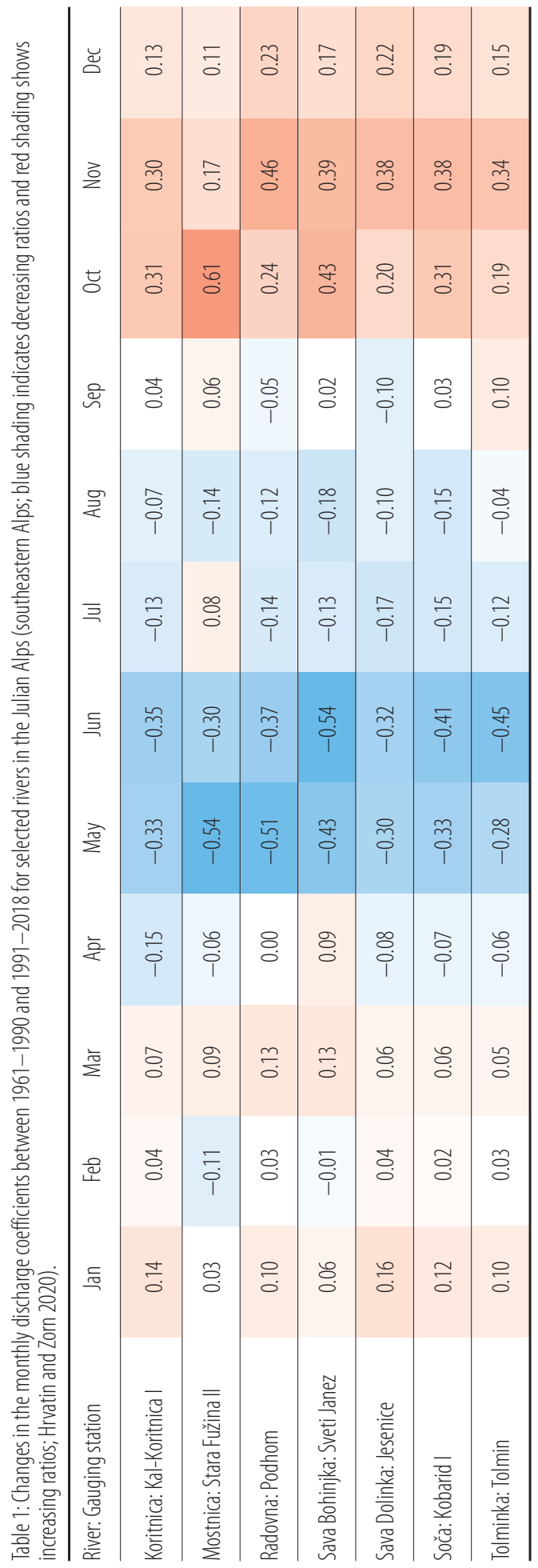


The paper on Antarctica is featured first and is dedicated to isotopic geochemistry of calcium carbonate encrustations in soils in Antarctica's Taylor Valley. These encrustations are important because they preserve records of geochemical, hydrological, and atmosphere processes affecting these soils. The results suggest, among other things, that the $\delta^{13} \mathrm{C}$ signature in the encrustations can be used to ascertain the difference between pedogenic and lacustrine carbonate in the soils studied. In addition, the $\delta^{18} \mathrm{O}$ data indicate that evaporation/sublimation of water, perhaps in thin films, plays a major role in the production of these encrustations (Lyons et al. 2020). Interestingly, also in the southeastern Alps, carbonate deposits recently exposed due to glacier retreat were studied as possible paleoenvironmental indicators (Lipar et al. 2021).

The second paper deals with geochemical analyses of the glacier ice, cave ice, meltwater (paper cover figure), and spring water in the southeastern Alps (Carey et al. 2020). This paper is to some extent a continuation of a paper published a year earlier (Carey et al. 2019). Whereas the 2019 paper is focused on ice in caves at elevations between approximately 1,100 and $1,500 \mathrm{~m}$, the paper in this special issue presents data from ice in caves at elevations between 2,350 and 2,450 m. Analyses of ice and meltwater from both Slovenian glaciers are also included.

The third and the fourth papers continue the journal's tradition of exploring glaciers in the southeastern Alps. The paper on the Triglav Glacier is already the tenth such paper published in the journal (see Section 9.1), but the first one to report in detail on changes in its thickness, volume, and mass balance. Previous papers primarily focused on changes in the glacier's area. The results show that the Triglav Glacier's mean thickness has thinned from approximately $40 \mathrm{~m}$ to less than $3 \mathrm{~m}$ since the mid- $20^{\text {th }}$ century, and that during this period the glacier's annual specific mass balance was $-0.45 \mathrm{~m}$ w.e. $\mathrm{a}^{-1}$ (Triglav Čekada and Zorn 2020).

The Skuta Glacier is examined for the fifth time in the journal (see Section 9.1), but this is the first time that its thickness is studied in detail. Although the area of the Skuta Glacier has not changed significantly over the past half-century, the average elevation of its upper edge has decreased by approximately $40 \mathrm{~m}$. The analyses show that the maximum seasonal snow cover depth at the end of the accumulation season is important for preservation of the glacier's thickness (Triglav Čekada et al. 2020).

The fifth (and last) paper in this special issue is also dedicated to very small glaciers and snowfields, but this time in southeastern Europe in general. Changes in the glaciers and snowfields in the Prokletije Mountains (Albania) and Durmitor Mountains (Montenegro) show high short-term variations over the past decade and a downward long-term trend (Gachev 2020), just like the two Slovenian glaciers in the southeastern Alps examined. Elsewhere across southern Europe, very small glaciers also survive at very low elevations $(2,000-2,500 \mathrm{~m})$, despite the unfavorable climate conditions. This is primarily the result of high levels of winter precipitation, which produces large snowfalls, and in some places this snow may last all year round, sustaining these glaciers even today (Hughes 2014; Hughes and Woodward 2017). On the other hand, the last three papers in the issue show that, because small glaciers are confined in karst depressions, topography and the karst surface also play a vital role in sustaining them. This also agrees with the findings of other researchers (e.g., Grunewald and Scheithauer 2010) that in the concluding stages of glacial degradation the impact of climate factors shows a relative decrease, whereas the impact of terrain increases.

In the southeastern Alps and elsewhere in southeastern Europe, permanent ice can still be found on the surface and in caves, which should be taken advantage of as soon as possible to secure the important paleoenvironmental data that this ice is storing before the data are lost forever.

The editors strives for the papers published in this special issue of Acta geographica Slovenica to not only serve as records of past research, but also stimulate further research and cooperation in this area.

ACKNOWLEDGEMENTS: The authors acknowledge financial support from The Ohio State University's Slovene Research Initiative and the Slovenian Research Agency research core funding Geography of Slovenia (P6-0101).

\section{References}

Bodin, X., Schoeneich, P., Deline, P., Ravanel, L., Magnin, F., Krysiecki, J.-M., Echelard, T. 2015: Mountain permafrost and associated geomorphological processes: recent changes in the French Alps. Journal of Alpine Research 103-2. DOI: https://doi.org/10.4000/rga.2885 
Matija Zorn, Blaž Komac, Anne Carey, Mauro Hrvatin, Rok Ciglič, Berry Lyons, The disappearing cryosphere in the ...

Boeckli, L., Brenning, A., Gruber, S., Noetzli, J. 2012: Permafrost distribution in the European Alps: calculation and evaluation of an index map and summary statistics. The Cryosphere 6. DOI: https://doi.org/ $10.5194 /$ tc-6-807-2012

Brook, E. J., Buizert, C. 2018: Antarctic and global climate history viewed from ice cores. Nature 558. DOI: https://doi.org/10.1038/s41586-018-0172-5

Carey, A., Smith, D., Welch, S., Zorn, M., Tičar, J., Lipar, M., Komac, B., Lyons, B. 2020: The geochemistry of ice in the Triglav area, Slovenia. Acta geographica Slovenica 60-2. DOI:10.3986/AGS.7420

Carey, A. E., Zorn, M., Tičar, J., Lipar, M., Komac, B., Welch, S. A., Smith, D. F., Lyons, W. B. 2019: Glaciochemistry of cave ice: Paradana and Snežna caves, Slovenia. Geosciences 9-2. DOI: https://doi.org/10.3390/ geosciences 9020094

Ciglič, R., Komac, B., Perko, D., Zorn, M. 2020: Zgodovina revije Acta geographica Slovenica. Geografski vestnik 92-2. DOI: https://doi.org/10.3986/GV92205

Climate Change Indicators: Lake Ice. United States Environmental Protection Agency, 2020. Internet: https://www.epa.gov/climate-indicators/climate-change-indicators-lake-ice (10. 10. 2020).

Colucci, R. R., Boccali, C., Žebre, M., Guglielmin, M. 2016a: Rock glaciers, protalus ramparts and pronival ramparts in the south-eastern Alps. Geomorphology 269. DOI: https://doi.org/10.1016/j.geomorph.2016.06.039

Colucci, R. R., Fontana, D., Forte, E., Potleca, M., Guglielmin, M. 2016b: Response of ice caves to weather extremes in the Southeastern Alps, Europe. Geomorphology 261. DOI: https://doi.org/10.1016/ j.geomorph.2016.02.017

Colucci, R. R., Guglielmin, M. 2019: Climate change and rapid ice melt: Suggestions from abrupt permafrost degradation and ice melting in an alpine ice cave. Progress in Physical Geography 43-4. DOI: https://doi.org/ $10.1177 / 0309133319846056$

Duvillard, P.-A., Ravanel, L., Deline, P. 2015: Risk assessment of infrastructure destabilisation due to global warming in the high French Alp. Journal of Alpine Research 103-2. DOI: https://doi.org/10.4000/rga.2896

Frantar, P. 2004: Analiza temperaturnega režima in pojava ledu na Bohinjskem jezeru. Ujma 17-18.

Frantar, P., Uhan, J. 2005: Vse manj ledu tudi na Bohinjskem jezeru. Internet: http://www.arso.si/vode/ publikacije\%20in\%20poro\%C4\%8Dila/Led_Bohinj.pdf (10.10.2020).

Gabrovec, M., Hrvatin, M., Komac, B., Ortar, J., Pavšek, M., Topole, M., Triglav Čekada, M., Zorn, M. 2014: Triglavski ledenik. Geografija Slovenije 30. Ljubljana. DOI: https://doi.org/10.3986/9789610503644

Gabrovec, M., Ortar, J., Pavšek, M., Zorn, M., Triglav Čekada, M. 2013: The Triglav Glacier between the years 1999 and 2012. Acta geographica Slovenica 52-2. DOI: https://doi.org/10.3986/AGS53202

Gabrovec, M., Bičík, I., Komac, B. 2019: Land registers as a source of studying long-term land-use changes. Acta geographica Slovenica 59-2. DOI: https://doi.org/10.3986/AGS.7349

Gachev, E. 2020: Small glaciers in the Dinaric Mountains after eight years of observation: On the verge of extinction? Acta geographica Slovenica 60-2. DOI: https://doi.org/10.3986/AGS.8092

Gams, I. 1955: Snežni plazovi v Sloveniji v zimah 1950-1954. Geografski zbornik 3.

Gams, I. 1961: Triglavsko brezno. Naše jame 3, 1-2.

Gams, I. 1971: Podtalne kraške oblike. Geografski vestnik 43.

Gibson, E. 2020: Single glacier lost enough ice to supply all NZers with drinking water - Niwa. Internet: https://www.stuff.co.nz/environment/climate-news/300038562/single-glacier-lost-enough-ice-to-supply-all-nzers-with-drinking-water-niwa (10. 10. 2020).

Gruber, S., Hoelzle, M., Haeberli, W. 2004: Permafrost thaw and destabilization of Alpine rock walls in the hot summer of 2003. Geophysical Research Letters 31-13. DOI: https://doi.org/10.1029/2004GL020051

Grunewald, K., Scheithauer, J. 2010: Europe's southernmost glaciers: response and adaptation to climate change. Journal of Glaciology 56-195. DOI: https://doi.org/10.3189/002214310791190947

Haeberli, W., Noetzli, J., Arenson, L., Delaloye, R., Gärtner-Roer, I., Gruber, S., Isaksen, K., Kneisel, C., Krautblatter, M., Phillips, M. 2010: Mountain permafrost: development and challenges of a young research field. Journal of Glaciology 56-200. DOI: https://doi.org/10.3189/002214311796406121

Hock, R., Rasul, G., Adler, C., Cáceres, B., Gruber, S., Hirabayashi, Y., Jackson, M., Kääb, A., Kang, S., Kutuzov, S., Milner, A., Molau, U., Morin, S., Orlove, B., Steltzer H. 2019: High mountain areas. IPCC Special Report on the Ocean and Cryosphere in a Changing Climate. Internet: https://www.ipcc.ch/site/assets/ uploads/sites/3/2019/11/06_SROCC_Ch02_FINAL.pdf (10.10.2020).

Hawkins, E. 2020: \#ShowYourStripes. University of Reading. Internet: https://showyourstripes.info/ (14. 12. 2020). Hrvatin, M. 1998: Discharge regimes in Slovenia. Geografski zbornik 38. 
Hrvatin, M., Zorn, M. 2017: Trendi pretokov rek v slovenskih Alpah med letoma 1961 in 2010. Geografski vestnik 89-2. DOI: https://doi.org/10.3986/GV89201

Hrvatin, M., Zorn, M. 2020: Climate and hydrological changes in Slovenia’s mountain regions between 1961 and 2018. Ekonomska i ekohistorija 16.

Hughes, P. D. 2014: Mediterranean glaciers and glaciation. Encyclopedia of Snow, Ice and Glaciers. Dordrecht. DOI: https://doi.org/10.1007/978-90-481-2642-2_640

Hughes, P. D., Woodward, J. C. (ed.) 2017: Quaternary glaciation in the Mediterranean mountains. Geological Society, London, Special Publications 433. DOI: https://doi.org/10.1144/SP433

Huss, M. 2011: Present and future contribution of glacier storage change to runoff from macroscale drainage basins in Europe. Water Resources Research 47-7. DOI: https://doi.org/10.1029/2010WR010299

Kaufmann, V., Kellerer-Pirklbauer, A., Lieb, G. K., Slupetzky, H., Avian, M. 2015: Glaciological studies at Pasterze Glacier (Austria) based on aerial photographs. Monitoring and modeling of global changes: A geomatics perspective. Dordrecht. DOI: https://doi.org/10.1007/978-94-017-9813-6_9

Kellerer-Pirklbauer, A., Lieb, G. K., Kaufmann, V. 2017: The Dösen Rock Glacier in Central Austria: A key site for multidisciplinary long-term rock glacier monitoring in the Eastern Alps. Austrian Journal of Earth Sciences 110-2. DOI: https://doi.org/10.17738/ajes.2017.0013

Kern, Z., Perșoiu, A. 2013: Cave ice - The imminent loss of untapped mid-latitude cryospheric palaeoenvironmental archives. Quaternary Science Reviews 67. DOI: https://doi.org/10.1016/j.quascirev.2013.01.008

Kolar, N. 2019: Ptuj, urejanje in varovanje mesta od 1800 do 1914. Ekonomska i ekohistorija 15.

Lipar, M., Pérez, A. M., Tičar, J., Pavšek, M., Gabrovec, M., Hrvatin, M., Komac, B., Zorn, M., Zupan Hajna, N., Zhao, J.-X., Drysdale, R. N., Ferk, M. 2021: Subglacial carbonate deposits as a potential proxy for a glacier's former presence. The Cryosphere 15. DOI: https://doi.org/10.5194/tc-15-17-2021

Lipar, M., Zorn, M., Perko, D. 2021: Ice caves. The International Encyclopedia of Geography. Chichester. DOI: https://doi.org/10.1002/9781118786352.wbieg2038

Luetscher, M., Jeannin, P., Haeberli, W. 2005: Ice caves as an indicator of winter climate evolution: A case study from the Jura Mountains. The Holocene 15-7. DOI: https://doi.org/10.1191/0959683605hl872ra

Lyons, B., Foley, K., Carey, A., Diaz, M., Bowen, G., Cerling, T. 2020: The isotopic geochemistry of $\mathrm{CaCO}_{3}$ encrustations in Taylor Valley, Antarctica: Implications for their origin. Acta geographica Slovenica 60-2 DOI: https://doi.org/10.3986/AGS.7233

Magnuson, J. J., Robertson, D. M., Benson, B. J., Wynne, R. H., Livingstone, D. M., Arai, T., Assel, R. A., Barry, R. G., Card, V., Kuusisto, E., Granin, N. G., Prowse, T. D., Stewart, K. M., Vuglinski, V. S. 2000: Historical trends in lake and river ice cover in the Northern Hemisphere. Science 289-5485. DOI: https://doi.org/10.1126/science.289.5485.1743

Mihevc, A. 2015: The influence of caves on the climate of the karst surface and karst permafrost. Zbornik radova: Međunarodni znanstveni simpozij Blidinje. Mostar.

Mihevc, A. 2018: Ice caves in Slovenia. Ice Caves. Amsterdam. DOI: https://doi.org/10.1016/B978-0-12811739-2.00030-9

Mihevc, A., Urbančič, T. 2019: Spremljanje premikov in oblikovanja poligonalnih tal v Skedneni jami s terestričnim laserskim skeniranjem. Raziskave s področja geodezije in geofizike 2018. Ljubljana.

Nared, J., Razpotnik Visković, N., Komac, B. 2015: Sustainable spatial development in the Alps. Acta geographica Slovenica 55-1. DOI: https://doi.org/10.3986/AGS.1969

Noetzli, J., Hoelzle, M., Haeberli, W. 2003: Mountain permafrost and recent Alpine rock-fall events: a GISbased approach to determine critical factors. Proceedings of the $8^{\text {th }}$ International Conference on Permafrost. Zürich.

Obu, J., Košutnik, J., Overduin, P. P., Boike, J., Blatnik, M., Zwieback, S., Gostinčar, P., Mihevc, A. 2018: Sorted patterned ground in a karst cave, Ledenica pod Hrušico, Slovenia. Permafrost and Periglacial Processes 29-2. DOI: https://doi.org/10.1002/ppp.1970

Ogrin, M. 2005: Measuring winter precipitation with snow cover water accumulation in mountainous areas. Acta geographica Slovenica 45-2. DOI: https://doi.org/10.3986/AGS45203

Ogrin, M., Ortar, J. 2007: The importance of water accumulation of snow cover measurements in mountainous regions of Slovenia. Acta geographica Slovenica 47-1. DOI: https://doi.org/10.3986/AGS47103 
Oliva, M., Žebre, M., Guglielmin, M., Hughes, P. D., Çiner, A., Vieira, G., Bodin, X., Andrés, N., Colucci, C. C., García-Hernández, C., Mora, C., Nofre, J., Palacios, D., Pérez-Alberti, A., Ribolini, A., RuizFernández, J., Sarıkaya, M. A., Serrano, E., Urdea, P., Valcárcel, M., Woodward, J. C., Yıldırım, C. 2018 : Permafrost conditions in the Mediterranean region since the Last Glaciation. Earth-Science Reviews 185. DOI: https://doi.org/10.1016/j.earscirev.2018.06.018

Pavšek, M. 2002: Snežni plazovi v Sloveniji. Geografija Slovenije 6. Ljubljana. DOI: https://doi.org/10.3986/ 9789612545000

Perșoiu, A., Lauritzen, S.-E. (eds.) 2018: Ice Caves. Amsterdam. DOI: https://doi.org/10.1016/C2016-0-01961-7

Perşoiu, A., Onac, B. P. 2019: Ice in caves. Encyclopedia of Caves. London DOI: https://doi.org/10.1016/B9780-12-814124-3.00066-2

Price, M. F., Borowski, D., Macleod, C., Rudaz, G., Debarbieux, B. 2011: Sustainable mountain development in the Alps: From Rio 1992 to Rio 2012 and beyond. Internet: http://www.fao.org/fileadmin/user_upload/ mountain_partnership/docs/ALPS\%20FINAL\%2020120228\%20RIO\%20Alps.pdf (10. 10. 2020).

Ranzani, A., Bonato, M., Ritesh Patro, E., Gaudard, L., De Michele, C. 2018: Hydropower future: between climate change, renewable deployment, carbon and fuel prices. Water 10-9. DOI: https://doi.org/10.3390/ w10091197

Ritter, F., Fiebig, M., Muhar, A. 2012: Impacts of global warming on mountaineering: A classification of phenomena affecting the alpine trail network. Mountain Research and Development 3-1. DOI: https://doi.org/10.1659/MRD-JOURNAL-D-11-00036.1

Show Your Stripes: heat continues in 2020. World Meteorological Organization, 2020. Internet: https://public.wmo.int/en/media/news/show-your-stripes-heat-continues-2020 (18. 6. 2020).

Slater, T., Lawrence, I. R., Otosaka, I. N., Shepherd, A., Gourmelen, N., Jakob, L., Tepes, P., Gilbert, L. 2020: Review Article: Earth's ice imbalance. The Cryosphere. [preprint] DOI: https://doi.org/10.5194/tc-2020-232

Šifrer, M. 1963: Nova geomorfološka dognanja na Triglavu: Triglavski ledenik v letih 1954-1962. Geografski zbornik 8.

Takács, K., Kern, Z. 2015: Multidecadal changes in the river ice regime of the lower course of the River Drava since AD 1875. Journal of Hydrology 529. DOI: https://doi.org/10.1016/j.jhydrol.2015.01.040

Tičar, J., Lipar, M., Zorn, M., Kozamernik, E. 2018: Triglavsko podzemlje. Triglav 240. Ljubljana. DOI: https://doi.org/10.3986/9789610500841

Triglav Čekada, M., Barbo, P., Pavšek, M., Zorn, M. 2020: Changes in the Skuta Glacier (southeastern Alps) assessed using non-metric images. Acta geographica Slovenica 60-2. DOI: https://doi.org/10.3986/AGS.7674

Triglav Čekada, M., Barborič, B., Zorn, M., Ferk, M. 2016: Lasersko skeniranje Slovenije in akumulacijske reliefne oblike v slovenskem visokogorju. Raziskave s področja geodezije in geofizike 2015. Ljubljana.

Triglav Čekada, M., Zorn, M. 2020: Thickness and geodetic mass balance changes for the Triglav Glacier (southeastern Alps) from 1952 to 2016. Acta geographica Slovenica 60-2. DOI: https://doi.org/10.3986/ AGS.7673

Triglav Glacier: Environmental indicators in Slovenia. Slovenian Environment Agency, 2019. Internet: http://kazalci.arso.gov.si/en/content/triglav-glacier (10. 10. 2020).

Urbanc, M., Pipan, P. 2013: Prihodnost turizma v Alpah v luči prilagajanja podnebnim spremembam: nekatere ugotovitve iz projekta ClimAlpTour. Geografski vestnik 85-1.

Volk Bahun, M. 2020: Mehanizmi pojavljanja snežnih plazov v slovenskih Alpah. Ph.d. Thesis, Fakulteta za humanistične študije. Koper.

Vreča, P., Brenčič, M., Sinjur, I., Vertačnik, G., Volk, M., Ortar, J., Torkar, A., Stibilj, V., Pavšek, P. 2013: Izotopska sestava padavin in snega na območju Julijskih Alp in Karavank. Raziskave s področja geodezije in geofizike 2012. Ljubljana.

Vrhovec, T. 2003: Podori v visokih alpskih stenah: podnebne spremembe spreminjajo obličje gora. Planinski vestnik 103-9.

Vrhovec, T. 2004: Odmrzovanje permafrosta in podori v visokih alpskih stenah. Ujma 17-18.

Water Management in a Changing Environment: Strategies against Water Scarcity in the Alps. Chambéry, 2011. Internet: https://openpub.fmach.it/retrieve/handle/10449/21596/4215/WaterManagementHandbook.pdf (10. 10. 2020).

Weber, M., Braun, L., Mauser, W., Prasch, M. 2010: Contribution of rain, snow- and icemelt in the upper Danube discharge today and in the future. Geografia Fisica e Dinamica Quaternaria 33-2.

Which area is covered? Interreg: Alpine Space, 2020. Internet: https://www.alpine-space.eu/about/the-programme/ which-area-is-covered- (10. 10. 2020). 
WMO Statement on the State of the Global Climate in 2019. World Meteorological Organization, 2020. Internet: https://library.wmo.int/doc_num.php?explnum_id=10211 (10.10.2020).

Zekollari, H., Huss, M., Farinotti, D. 2019: Modelling the future evolution of glaciers in the European Alps under the EURO-CORDEX RCM ensemble. The Cryosphere 13. DOI: https://doi.org/10.5194/tc-13$1125-2019$

Zorn, M., Komac, B. 2010: The history of Acta geographica Slovenica. Acta geographica Slovenica 50-1. DOI: https://doi.org/10.3986/AGS5010

\section{Appendix: A chronological list of papers on the cryosphere published in Acta geographica Slovenica / Geografski zbornik}

\subsection{Contemporary glaciers}

Meze, D. 1955: Ledenik na Skuti. Geografski zbornik 3.

Melik, A. 1955: Ledenik na Triglavu in na Skuti. Opazovanje ledenika na Triglavu in na Skuti: predgovor. Geografski zbornik 3.

Meze, D. 1955: Triglavski ledenik. Geografski zbornik 3.

Šifrer, M. 1963: Nova geomorfološka dognanja na Triglavu: Triglavski ledenik v letih 1954-1962. Geografski zbornik 8.

Šifrer, M., Košir, D. 1976: Nova dognanja na Triglavskem ledeniku in ledeniku pod Skuto. Geografski zbornik 15.

Košir, D. 1986: Ledenik pod Skuto v letih 1974-1985. Geografski zbornik 26.

Šifrer, M. 1986: Triglavski ledenik v letih 1974-1985. Geografski zbornik 26.

Gams, I. 1994: Changes of the Triglav glacier in the 1955-94 period in the light of climatic indicators. Geografski zbornik 34

Gabrovec, M. 1998: The Triglav glacier between 1986 and 1998. Geografski zbornik 38.

Triglav Čekada, M., Kosmatin Fras, M., Gvozdanovič, T. 2000: Monitoring of glacier surfaces with photogrammetry, a case study of the Triglav glacier. Geografski zbornik 40.

Đurović, P. 2009: Reconstruction of the pleistocene glaciers of Mt. Durmitor in Montenegro. Acta geographica Slovenica 49-2. DOI: https://doi.org/10.3986/AGS49202

Đurović, P. 2012: The Debeli Namet glacier from the second half of the 20th century to the present. Acta geographica Slovenica 52-2. DOI: https://doi.org/10.3986/AGS52201

Gabrovec, M., Ortar, J., Pavšek, M., Zorn, M., Triglav Čekada, M. 2013: The Triglav Glacier between the years 1999 and 2012. Acta geographica Slovenica 52-2. DOI: https://doi.org/10.3986/AGS53202

Zorn, M., Komac, B. 2013: Contribution of Ivan Gams to Slovenian physical geography and geography of natural hazards. Acta geographica Slovenica 53-1. DOI: https://doi.org/10.3986/AGS53102

Gachev, E. 2020: Small glaciers in the Dinaric Mountains after eight years of observation: On the verge of extinction? Acta geographica Slovenica 60-2. DOI: https://doi.org/10.3986/AGS.8092

Triglav Čekada, M., Barbo, P., Pavšek, M., Zorn, M. 2020: Changes in the Skuta Glacier (southeastern Alps) assessed using non-metric images. Acta geographica Slovenica 60-2. DOI: https://doi.org/10.3986/AGS.7674

Triglav Čekada, M., Zorn, M. 2020: Thickness and geodetic mass balance changes for the Triglav Glacier (southeastern Alps) from 1952 to 2016. Acta geographica Slovenica 60-2. DOI: https://doi.org/10.3986/ AGS.7673

\subsection{Pleistocene glaciation}

Melik, A. 1954: Nova glaciološka dognanja v Julijskih Alpah. Geografski zbornik 2

Melik, A. 1955: Nekaj glacioloških opažanj iz zgornje Doline. Geografski zbornik 3.

Šifrer, M. 1955: Dolina Tolminke in Zalašce v pleistocenu. Geografski zbornik 3.

Šifrer, M. 1959: Obseg pleistocenske poledenitve na Notranjskem Snežniku. Geografski zbornik 5.

Melik, A. 1961: Vitranc, Zelenci in Bovško: geomorfološke študije iz zahodnih Julijskih Alp. Geografski zbornik 6. 
Šifrer, M. 1969: Kvartarni razvoj Dobrav na Gorenjskem. Geografski zbornik 11.

Meze, D. 1974: Porečje Kokre v pleistocenu. Geografski zbornik 14.

Kunaver, J. 1983: Geomorfološki razvoj Kaninskega pogorja s posebnim ozirom na glaciokraške pojave. Geografski zbornik 22.

Gams, I. 1992: Prispevek k mladokvartarni geomorfologiji v Zgornjesavski dolin. Geografski zbornik 32.

Gams, I. 2008: Geomorphology of Pohorje mountains. Acta geographica Slovenica 48-2. DOI: https:/doi.org/ 10.3986/AGS48201

Tintor, W., Andrič, M. 2014: Lateglacial studies in the western valleys of the Italian Julian Alps and in the Koritnica valley. Acta geographica Slovenica 54-1. DOI: https://doi.org/10.3986/AGS54101

\subsection{Snow and avalanches, ice and geochemistry}

Furlan, D. 1955: Snežne padavine v Sloveniji 11.-15. februarja 1952. Geografski zbornik 3.

Gams, I. 1955: Snežni plazovi v Sloveniji v zimah 1950-1954. Geografski zbornik 3.

Melik, A. 1955: Snežni plazovi v Sloveniji: predgovor. Geografski zbornik 3.

Furlan, D. 1961: Padavine v Sloveniji. Geografski zbornik 6.

Gams, I. 1961: Snežišča v Julijskih Alpah. Geografski zbornik 6.

Šifrer, M. 1961: Snežišča v Kamniških Alpah. Geografski zbornik 6.

Košir, D. 1965: Klimatske razmere na Kredarici (od 1. avgusta 1954 do 31. oktobra 1962). Geografski zbornik 9. Šifrer, M. 1976: Geografski učinki žleda v gozdovih okrog Idrije ter Postojne. Geografski zbornik 16.

Ogrin, M. 2005: Measuring winter precipitation with snow cover water accumulation in mountainous areas. Acta geographica Slovenica 45-2. DOI: https://doi.org/10.3986/AGS45203

Ogrin, M., Ortar, J. 2007: The importance of water accumulation of snow cover measurements in mountainous regions of Slovenia. Acta geographica Slovenica 47-1. DOI: https://doi.org/10.3986/AGS47103

Carey, A., Smith, D., Welch, S., Zorn, M., Tičar, J., Lipar, M., Komac, B., Lyons, B. 2020: The geochemistry of ice in the Triglav area, Slovenia. Acta geographica Slovenica 60-2. DOI:10.3986/AGS.7420

Lyons, B., Foley, K. , Carey, A., Diaz, M., Bowen, G., Cerling, T. 2020: The isotopic geochemistry of $\mathrm{CaCO}_{3}$ encrustations in Taylor Valley, Antarctica: Implications for their origin. Acta geographica Slovenica 60-2 DOI: https://doi.org/10.3986/AGS.7233

Zorn, M., Komac, B., Carey, A., Hrvatin, M., Ciglič, R., Lyons, B. 2020: The disappearing cryosphere in the southeastern Alps: Introduction to special issue. Acta geographica Slovenica 60-2 DOI: https://doi.org/ 10.3986/AGS.9396 